DOI: https://doi.org/10.34069/AI/2021.39.03.22

\title{
Nature and significance of the State's criminal law policy
}

\section{Сутність і значення кримінально-правової політики держави}

Received: March 30, 2021

Abstract

The purpose of the article is to analyze the criminal law policy of the State as one of the main elements of the fight against crime. The subject of the study is the criminal law policy of the State. Methodology: dialectical method, monographic method, logical method, comparative method, system and structural method, method of generalization are used in the course of the research. Research results: The essence and significance of the criminal law policy of the State, its role and place in the general system of legal relations are revealed and the importance of such a mechanism at the national level is emphasized. The current state and level of criminal law policy of the State are criticized. Practical implications: The components of criminal law policy and their relationship with other components of public policy in general are studied. The directions of criminal law policy and its levels are revealed. Value / originality: The limited possibility of the law on criminal liability in the system of social control is emphasized. The general purpose of control over the effectiveness of criminal law policy is indicated.
Accepted: May 1, 2021

\author{
Written by: \\ Vorobey Petro ${ }^{82}$ \\ https://orcid.org/0000-0003-2470-1920 \\ Felyk Vasil ${ }^{83}$ \\ https://orcid.org/0000-0002-9326-4317 \\ Niebytov Andrii ${ }^{84}$ \\ https://orcid.org/0000-0002-8493-3064 \\ Matviichuk Valerii ${ }^{85}$ \\ https://orcid.org/0000-0003-3459-0056 \\ Vorobey Olena ${ }^{86}$ \\ https://orcid.org/0000-0002-7106-148X
}

\begin{abstract}
Анотація
Метою статті $\epsilon$ аналіз кримінально-правової політики держави як одиного із основних елементів боротьби із злочинністю. Предмет дослідження: Предметом дослідження $\epsilon$ кримінально-правова політики держави. Методологія: У ході дослідження були використані діалектичний метод, монографічний метод, логічний метод, порівняльний метод, системний та структурний метод, метод узагальнення. Результати дослідження: Розкривається сутність і значення кримінальноправової політики держави, роль і місце в загальній системі правовідносин та підкреслюється важливість такого механізму на загальнодержавному рівні. Піддається критиці сучасний стан та рівень кримінально-правової політики держави. Практичні наслідки: Досліджуються складові кримінально правової політики та їх взаємозв'язок з іншими складовими державної політики в цілому. Розкриваються напрями кримінально-правової політики та іï рівні. Цінність / оригінальність: Підкреслюється обмежена можливість закону про кримінальну відповідальність в системі соціального контролю. Вказана загальна мета контролю за ефективністю кримінально-правової політики.
\end{abstract}

\footnotetext{
${ }^{\mathbf{8 2}}$ Doctor of Law, Professor, Head of the Department of Criminal Law, Procedure and Criminology of Kyiv Institute of Intellectual Property and Law of the National University "Odesa Law Academy", Ukraine.

${ }^{\mathbf{8 3}}$ Doctor of Law, Professor, Director of Kyiv Institute of Intellectual Property and Law of the National University "Odesa Law Academy", Ukraine.

${ }^{\mathbf{8 4}}$ Doctor of Law, Associate Professor, Head of the Main Department of the National Police in the Kiev region, Ukraine.

${ }^{85}$ Doctor of Law, Professor, Professor of the Department of Criminal Law, Procedure and Criminology of Kyiv Institute of Intellectual Property and Law of the National University "Odesa Law Academy", Ukraine.

${ }^{86} \mathrm{PhD}$ in Law, Associate Professor, Professor of the Department of Forensic Support and Forensics of the Educational and Scientific Institute № 2 of the National Academy of Internal Affairs, Ukraine.
} 
Key words: criminal law policy, law-making and law-enforcement activity, views, control, subjects of criminal law policy.

\section{Introduction}

Criminal law policy is a component of State policy in the area of crime control. As Ardestani (2017, p. 169) correctly states that criminal policy is, first of all, one of the elements of the preventive system. The implementation of such policy and its effectiveness, role, place and significance depends on many factors, among which the political will and strategy of the State occupy the main place. The criminal law policy of the State is reflected in the specific role of criminal liability legislation. The political strategy of any State in general and the strategy of our State in particular are implemented, inter alia, through one of the areas - criminal law policy. To cover this important issue, it is necessary to develop a strategic path, conceptual framework, analyze general and conceptual issues. To implement such a plan, it is necessary to determine the stages, methods and areas of control over criminal law policy. The most important factors in achieving the objective are the subject of such monitoring. Legal consciousness of society, legal psychology and legal ideology, the high level of which will ensure the achievement of the State's goal in the implementation of criminal law policy in the fight against crime also play an important role.

So the purpose and the task of the study is the attempt to emphasize the essence and importance of criminal law policy in public policy in the overall strategy to combat crime. The possibility and recommendations for further scientific developments of this important issue for the state are highlighted. It is proposed to strengthen the control over the criminal law policy by State agencies and civil society.

\section{Methodology}

The methodological basis for the article is the set of general and special methods and techniques of scientific knowledge. Dialectical method helps to provide a comprehensive analysis of the criminal law policy of the State as one of the main elements of the fight against crime, in particular: its role and place in the general system of legal relations, its components and their relationship with other components of public policy. Monographic method is used in the process of examining the works of Ukrainian and foreign
Ключові слова: кримінально-правова політика, правотворча та правоохоронна діяльність, погляди, контроль, суб'єкти кримінальноправової політики.

scientists, who examined the problems of the studied issue at different stages of the establishment of the latter. Logical method is applied for the interpretation of the concepts of criminal law policy, criminal law psychology, lawmaking and law enforcement activities, criminal law ideology, criminal law views, control and directions of criminal law policy, subjects of criminal law policy. Comparative method allows to compare the views of different scientists on the issue under consideration. System and structural method is used to identify the subjects of criminal law policy and their role in the implementation of the criminal law policy of the State. The method of generalization is applied to formulate the relevant conclusions and suggestions.

\section{Literature Review}

The challenges of modern history call for a deeper approach to crime control, implementing criminal law policy as a component of public policy. Well-formed, well-calibrated and strategically based criminal law policy is rather essential. Insufficient attention was paid to this issue in the recent history of the State, as evidenced by the small number of scientific studies. The works of domestic scholars provided only the theoretical basis for the formation and development of criminal law policy in Ukraine. Existing scientific research testifies to the problems of development and urgent needs in the development of both the general doctrine of the fight against crime and the concept of criminal law policy of the State.

One of the main elements of the relevant strategy of the State is the development of criminal law and legislation. It is in the light of the specific role of the law on criminal responsibility that the domestic policy of the State is clearly reflected. However, a political strategy cannot exist independently (in isolation), and therefore it is implemented through one of the State's criminal law policies. The concept and the content of criminal law policy are understood through a common dialectical methodology, which will indicate its place and role in the fight against crime. 
To solve this important task, it is necessary to develop an appropriate conceptual framework, to analyze general and conceptual problems.

Such prominent thinkers of the 18th century as Voltaire, C. Beccaria, S. Montesquieu, Morelli, and others considered the problems of criminal law policy. In the XIX century, Liszt, Prince, Ferry, Tarde and others criminologists paid considerable attention to criminal law policy.

Franz von Liszt (2004, p. 7) devoted a special work named "Tasks of criminal policy" to the issues of criminal law policy and defined criminal policy as a set of grounds based on scientific research into the causes of crime and acts of punishment; the grounds, on which the state through punishment and related institutions should fight crime. "

The first thorough study of this problem in domestic science belongs to Chubynskkyi (2008, p. 64). He studied the relationship between criminal policy and the science of criminal (substantive) law. In 1865, Professor Nekliudov (2014, p. 209) noted that "criminal policy of the State, which is based on criminal statistics, will be the wisdom of the State, against which any struggle will be powerless, because each such measure will not be created artificially, but it is produced by life, and life cannot counteract its own needs and benefits".

Prominent scientists of the 19th and early 20th centuries Bilohryts-Kotliarevskyi, Vladymyrov, Hordiienko, Danylevych, Kistiakivskyi and others have made a significant contribution to the development of ideas of criminal law policy.

In Soviet times, Hernet, Hertsenzon, Estrin, Piontkovskyi, Sharhorodsky and others paid attention to this issue.

During the period of Stalin's personality cult, research in the field of criminal law policy was long stopped and was essentially banned. It was not until the late 1970's that the scholars returned to the issue.

The works of domestic scholars Burchak, Korzhanskoh, Mykhailyk, Matyshevsko, Tatsii and other criminologists gave a theoretical basis for the formation and development of criminal law policy in Ukraine. At the same time, insufficient fundamental works are devoted to this issue. In 2004 the first monograph of Mytrofanov (2004) was published, which was devoted to the analysis of criminal law policy. In
2005 the monograph of Fris (2005) on similar issues was published. Recently, Kozych (2020) defended his doctoral dissertation, which is devoted to criminal law policy.

Insufficient number of scientific researches testifies to the educational need to develop both the general doctrine of fight against crime, and the doctrine and the concept of criminal law policy of the State. To date, these issues are not clearly defined. Despite the changes in socioeconomic relations, the legislation of Ukraine on criminal liability is not only unstable, but on the contrary, it changes with the speed of arithmetic progression.

\section{Results and Discussion}

Some scholars and politicians came to write the new Criminal Code of Ukraine, although the current Criminal Code was adopted only in 2001. The round table on the topic: "Draft of the new Criminal Code of Ukraine: problems and prospects", which was held online on December 11,2020 on the basis of the Kyiv Institute of Intellectual Property and Law of the National University "Odessa Law Academy" demonstrated that there are no useful innovations in the protection of constitutional human and civil rights and freedoms and no concept of legislative development. We also do not understand the architect itself and the imposition of new unnecessary deadlines, etc. All this indicates a desire to show creative, scientific and legislative activity and a tendency to Western "standards". Ukrainian legislation should be, first of all, national, and not copied from other countries. It should be acknowledged that some novelties in the legislation of Ukraine are really based on international acts ratified by Ukraine and there are no objections to this. However, some proposals are not only inappropriate, but also harmful due to their chaos and political emotionality. All this indicates the lack of stability of legislation.

Criminal law policy is part of all public policy. It should be assumed that the concept of politics is a "general direction, the nature of the activities of a particular class or political party" (Mykhailenko 1959, pp. 541 - 542). Criminal law policy is a direction of combating crime and is based on the application of the law on criminal liability. It is based on laws and other important decisions of State and public authorities. The ratio of the concepts of general, special and specific is the ratio of "legal policy", "policy in the area of crime" and "criminal policy". The 
content of legal policy, objectively determined by the will of the people (civil society), is actually mediated by its respected institutional representative - the State. This is due to the fact that the vast majority of domestic and foreign policy of the State is regulated by law, the legislative process, the introduction of political and legal decisions, embodied in regulatory forms and based on international legal principles (Panov 2001, p. 36). Many scholars support the State's criminal law policy. Danshyn and Zelinskyi (1992, p. 30) denied its existence, saying that "it (such a policy) was developed and implemented in Soviet times". Clearly, such view cannot be accepted, as democracy does not in any way contradict criminal law policy. On the contrary, it makes it possible to ensure maximum protection of human and civil rights and freedoms.

Criminal law policy develops the concept, strategy and tactics, principles and goals, the fight against crime and is transformed into the law on criminal liability, acts of official interpretation of criminal law and decisions of the Plenum of the Supreme Court of Ukraine.

Criminal law policy is determined depending on the state of the fight against crime. The analysis of the criminogenic situation is developed and implemented through certain areas of criminal law policy. These issues are important in the planning and development of criminal law policy at the micro level, which can be different. In this case we are talking about the relevant regions, where the directions of criminal law policy will be determined.

In accordance with the tasks facing the State in the fight against crime, the appropriate levels of criminal law policy should be identified, which include doctrinal, legislative and law enforcement levels. There are relevant participants in the implementation of criminal law policy at all these levels (court, prosecutor's office, police, Security Service, penitentiary authorities, scientists, citizens, etc.).

The subjects of criminal law policy are the Verkhovna Rada of Ukraine, the President of Ukraine, the Cabinet of Ministers of Ukraine, the Constitutional Court of Ukraine and the Supreme Court of Ukraine. As one can see, the subjects of criminal law policy are only those state bodies that form it. Participants in criminal law policy only act in the area of its protection.

Having an inseparable link with criminal law, criminal law policy occupies a central place in the fight against crime and forms the legal basis for this fight.

The tasks facing criminal law policy are determined by its essence. Understanding the content of criminal law policy determines its relationship with criminal law consciousness, criminal law ideology and criminal law psychology.

Criminal law consciousness of society in general and an individual citizen in particular is an element of general legal awareness, which is a set of the views on the fight against crime. Legal awareness in general operates at both the general and individual levels. It directly affects the studied issue through the prism of criminal law psychology. Besides, criminal law ideology in conjunction with criminal law psychology forms a criminal law consciousness. The latter, in turn, is a component of criminal law policy. Criminal law is subject to criminal law policy.

The level of crime depends on the correct and balanced criminal law policy of the State. Policy cannot be understood and disclosed without an in-depth analysis of law enforcement practice. Further improvement of the current legislation on criminal liability, its development and updating is focused on the conditionality of criminal law prohibitions. Only the study of the nature of criminal law phenomena can answer these questions. One or another act can be considered criminal from the socio-political situation and from the socio-psychological views of society. It is not possible to criminalize future phenomena, which may be criminalized.

They can be recognized as such only when they pose a threat and danger to an individual, society and the State. The legislator just provides correct criminal law assessment of negative phenomena when it is proved to be harmful or threatening to public relations. The law on criminal liability will be effective and efficient when the legal assessment reflects the need for its application. This is a kind of statement of the objective need to establish a criminal prohibition and enshrine it in the law on criminal liability. This does not mean that the legislator has the role of registrar of relevant social indicators without freedom of choice in decision-making.

In this case, the legislator is a kind of diagnostician in response to such changes. He should timely regulate the relevant types of social behavior. Changes in legal regulation depend on changes in social life. The law-making process is not limited to the establishment or abolition of 
criminal liability for certain acts. It addresses the issue of determining the degree of criminal regression, which is associated with penalization and de-penalization.

This process can be influenced by other factors (own rating, incomplete awareness of objective reality, etc.).

The link between crime policy and criminal law is legislative activity, and legislation itself is the result of crime policy.

The relevant stages of criminal law are important components of criminal law policy. They are:

collecting information about adverse events; their analysis;

forecasting;

formulation of criminal law;

its publication and application;

analysis of its effectiveness and cancellation.

The basis of policy is the relevant theory. The theory of penalization and de-penalization is the scientific basis for criminal law policy in the area of lawmaking.

There was a view on criminal repression as the main means of general and special prevention in the criminal law doctrine for a long time. Prevention of crime only by limiting the functions of the law has led to various changes in the fight against crime by means of criminal repression, or, conversely, to a skeptical view of the possibilities and capabilities of the law.

Despite the possibilities of the law on criminal liability, they are quite limited in the system of social control. Criminal law policy should create a single theoretical concept of criminalization and penalization of acts. The legislation of Ukraine on criminal liability should be considered scientifically substantiated if it covers the range of acts that can be fought and includes those acts that have lost public danger.

Criminal law policy is impossible without appropriate acts of interpretation of the law on criminal liability. This is especially important in the process of creating new legislation. All this requires a unification of approaches to the understanding and application of norms, which can be achieved only on the basis of universally binding acts of interpretation. The resolutions of the Plenum of the Supreme Court of Ukraine (Official web-site of the Supreme Court of Ukraine 2018), which address the issues of the practice of consideration of certain categories of criminal proceedings by general courts, are of particular importance in this matter.

These provisions are not laws, but they are as close as possible to the acts of interpretation of the law on criminal liability by their nature and are binding on the judiciary and law enforcement agencies. These resolutions reveal the features and directions of criminal law policy in the area of application of the law and its content. They are also of great importance for the conceptual apparatus of law enforcement.

In order to adopt the Criminal Code of Ukraine in 2001 (Law No. 2341-III, 2001), the decisions of the Plenum of the Supreme Court of Ukraine were devoted to important issues of criminal law policy in the area of combating crime and the application of the law on criminal liability. They (resolutions) played an important role in the implementation of the criminal law policy of the State, especially during the adoption of the new legislation on criminal liability.

The main aspect in the implementation of any program and especially in criminal law policy is the implementation of control at all stages. However, as noted above, the issue of anti-crime policy in general and criminal law policy in particular has received some attention, but the issue of control over them has not received proper scientific analysis and development. Only Boskholov (1999) paid attention to this issue in his monograph "Fundamentals of Criminal Policy".

The maximum increase in the effectiveness of criminal law policy is the general control over its implementation. This task can be achieved through the appropriate concept of criminal law policy for the general purpose of civil society, as well as its practical implementation.

Criminal law policy is implemented through various types of control (parliamentary, judicial, law enforcement control, public and scientific). The Constitution of Ukraine (Law No. 254k/96VR, 1996) defines the control powers of the Verkhovna Rada of Ukraine (Articles 85, Parts 6, 13, 33, 34; Article 89, Parts 3, 4, 5) and the Rules of the Rules of the Verkhovna Rada of Ukraine (Law No. 1861-VI, 2010) (Section 8). The powers of the Parliament to exercise parliamentary control are enshrined in Part 13, Art. 85 of the Constitution of Ukraine; they lie in hearing the reports of the Cabinet of Ministers of Ukraine, individual ministers, Heads of other 
State and executive bodies, standing committees, individual deputies through parliamentary inquiries and receiving answers to them. Unfortunately, there are still many cases of formal attitude to such control by the abovementioned bodies and officials.

The control functions of the Verkhovna Rada of Ukraine are not regulated by the Constitution of Ukraine (Law No. 254k/96-VR, 1996). The Rules of the Verkhovna Rada of Ukraine (Law No. 1861-VI, 2010) (Article 8. 1. 1) deal with the principles of control activity of this agency in more detail: "The Verkhovna Rada of Ukraine, in accordance with the powers established by the Constitution of Ukraine, directly or through its bodies monitors the constitutional rights, freedoms and responsibilities of the citizens of Ukraine, compliance with laws and other acts it adopts, the implementation of national programs and budget, as well as officials whom it elects, appoints or approves".

The judiciary controls criminal law policy in two ways. The Supreme Judicial Control is exercised by the Constitutional Court of Ukraine by making decisions on the conformity of laws with the Basic Law of the State and in interpreting their content.

The second way of control of criminal law policy is the control of common courts, which is carried out when considering criminal proceedings by courts of first instance, courts of appeal and courts of cassation. Such control is exercised by the court through an appropriate assessment of the subject of criminal law. This kind of control has important implications for the implementation of justice and the protection of the fundamental rights of individuals (Rahmati, Sheidaeian, MirKhalili, \& Darabi, 2018, p. 189).

Besides, there is control over the level of compliance with the requirements of the law on criminal liability by law enforcement agencies. In case of violation of these regulations, the relevant subjects of legal relations are prosecuted.

In our opinion, the demands of civil society are the most important and democratic lever of the control over criminal law policy. Art. 5 of the Constitution of Ukraine (Law No. 254k/96-VR, 1996) states that the people are the bearers of sovereignty and the only source of power in Ukraine. The people exercise power directly and through bodies of state power and bodies of local self-government. . The people participate in the development of the approaches to the formation of criminal law policy, analysis of law enforcement activities (public councils, supervisory boards, participation in court hearings, etc.).

Professor Boskholov (1999, p. 261) notes in this regard: "the purpose of civil control is to ensure the effectiveness of criminal justice, legality in the activities of criminal justice bodies, restoration of violated rights and freedoms of citizens".

Broad sections of the population are involved in public monitoring of criminal law policy. This makes it possible to take greater account of criminal law awareness and its possibilities, psychology and criminal law ideology, which are within the scope of the tasks of criminal law policy.

In addition to the above areas of control of criminal law policy, there is also scientific control, which, in fact, does not have control functions. However, this does not mean that science stands aside from these processes. Scientifically substantiated approaches to the optimal directions of development of the theoretical basis for criminal law policy provide an opportunity to better implement such policy. Such scientific activity is a critical assessment, control over the planning and implementation of criminal policy by the scientific community.

As noted above, the lack of fundamental researches on criminal law policy is not limited to the absence of such work. Such work is carried out at the level of individual institutions and norms, which are also to a certain extent of a control nature.

\section{Conclusion}

During the years of Ukraine's independence, many efforts have been made to update the system of legislation at the legislative level, including the adoption of the Constitution of Ukraine. The law enforcement function has been significantly expanded, new law enforcement agencies have been created, and positive changes have taken place in the judiciary. At the same time, there have been no significant changes to improve the fight against crime, especially in terms of control over criminal law policy. The crime rate is growing every year and this trend continues.

The methods of applying control over criminal law policy are negatively affected by the lack of appropriate developed regulatory framework. 
The control over criminal law policy exists, despite shortcomings in the development of the necessary regulatory framework. The relevant methods control this policy at each level. To improve the control in the area of criminal law policy, it is necessary to develop a regulatory framework for the implementation of these tasks. We are talking about not of separate law, but of adopting a law to regulate certain social relations concerning the criminal law policy of the State, and, in particular, the issues of control over its further development and effective implementation. This will provide an opportunity to anticipate its prospects and the ways of further improvement of Ukraine's progressive movement into the European and World Community.

\section{References}

Ardestani, A. (2017). Iran's criminal policy regarding economic corruptions. Amazonia Investiga, 6(11), 168-179. Retrieved from https://amazoniainvestiga.info/index.php/amazo nia/article/view/607

Boskholov, S. (1999). Fundamentals of criminal policy. Constitutional, criminological, criminal law and information aspects. Moskow: YurInfor, 1999.

Chubynskkyi, M. (2008). Essays on criminal policy (the concept, history and main problems of criminal policy as an integral element of the science of criminal law). Moskow: INFRA-M. https://search.rsl.ru/ru/record/01003329052

Danshyn, I. and Zelinskyi, A. (1992). Criminal policy: pros and cons. In: "Law of Ukraine", Num. 8, pp. 29 - 36.

Fris, P. (2005). Essay on the history of criminal law policy of Ukraine: a monograph. Kyiv: Attica.

Kozych, I. (2020). Criminal law policy: functions and functioning: a monograph. Ivano-Frankivsk: Suprun V. P.
Law No. 1861-VI-2010. Official Gazette of the Verkhovna Rada of Ukraine, Kyiv, Ukraine, February 02, 2010.

Law No. 2341-III-2001. Official Gazette of the Verkhovna Rada of Ukraine, Kyiv, Ukraine, April 05, 2001.

Law No. 254k/96-VR-1996. Official Gazette of the Verkhovna Rada of Ukraine, Kyiv, Ukraine, June 28, 1996.

Liszt, F.V (2004). Tasks of criminal policy. Crime as a socio-pathological phenomenon. Moskow:

INFRA. http://publ.lib.ru/ARCHIVES/L/LIST_Franc_fo n/_List_F._fon.html

Mykhailenko, P. (1959). Essays on the history of criminal law of the Ukrainian SSR. Part 1. Kyiv: Publishing House ANURSR.

Mytrofanov, A. (2004). The main directions of criminal law policy in Ukraine: formation and implementation. Odesa: Odesa National University of Internal Affairs.

Nekliudov, N. (2014). Berner's Criminal Law Textbook: translation with additions and appendices. Saint-Petersburg: Publishing House "Lan".

https://ua1lib.org/book/2893626/da1d0f?id=289 $3626 \&$ secret $=$ da1d0f

Official web-site of the Supreme Court of Ukraine (2018). The powers of the Plenum. https://supreme.court.gov.ua/supreme/pro_sud/p ovnovagennya/

Panov, M. (2001). Legal policy as a universal phenomenon of social life. Law of Ukraine, Num. $8, \quad$ pp. 36-40. http://ec.lib.vntu.edu.ua/DocDescription?doc_id $=73993$

Rahmati, M., Sheidaeian, M., MirKhalili, S., \& Darabi, S. (2018). Principle of supervision of criminal procedure. Amazonia Investiga, 7(14), 187-196.

Retrieved from https://amazoniainvestiga.info/in dex.php/amazonia/article/view/505 